\title{
DESCRIPTION OF A NEW TOAD FROM CUBA.
}

\author{
By Leonhard Stejneger, \\ Curator, Division of Reptiles and Batrachians.
}

Two species of toads, both belonging to the section of the genus $B u f o$, in which the skin of the head has become involved in the ossification of the skull, have long been known to occur in Cuba, namely, $B$. peltocephalus, which is a large and common species, and B. empusus, somewhat smaller and of more local distribution. Both are confined to the island (the former, at least, also inhabiting the Isle of Pines), with related, though not closely allied, species in Haiti, Porto Rico, and Central America.

The species here to be described belongs to an entirely different section of the genus, and the skin of the top of the head is not only not involved in the cranial ossification, but has not even a trace of the bony ridges so characteristic of most toads. It was collected by Messrs. William Palmer and J. A. Riley during their expedition to Cuba in 1900.

BUFO LONGINASUS, new species.

Diagnosis. - No cranial bony ridges; first finger shorter than second; toes nearly fully webbed; skin smooth, pustulous, but without asperities; snout conical, projecting, pointed, with the nostrils near the tip; parotoids enormous, their length almost equaling their distance from the groin.

Habitat. - Cuba.

Type-Cat. No. 27419, U. S. N. M.; El Guama, Pinar del Rio, Cuba; William Palmer and J. A. Riley, collectors; March 9, 1900.

Description of type.-Adult male: Head and body depressed, nearly flat above; snout concave along median line, conical, projecting, pointed; nostrils near the tip of snout and close together; canthus rostralis rounded; interorbital width much greater than width of upper eyelid; tympanum indistinct, about half the diameter of the eye; first finger shorter than second, with a pad of dark brown nuptial asperities on top and side of basal portion; tips of finger and toes slightly

Proceedings U. S. National Museum, Vol. XXVIII-No. 1406.

Proc. N. M. vol. xxviii-04-49 
swollen; toes nearly fully webbed; subarticular tubercles well developed, double; inner metatarsal tubercle moderate, not prominent, outer conical; a tarsal fold, the distal end of which resembles the inner metatarsal tubercle; tibio-tarsal articulation of hind leg extended forward along the side of the body, reaches halfway between insertion of fore leg and tympanum; skin above smooth with irregular smooth, distinctly pitted pustules separated posteriorly and on sides by anastomosing furrows; parotoids enormous, their length almost equaling

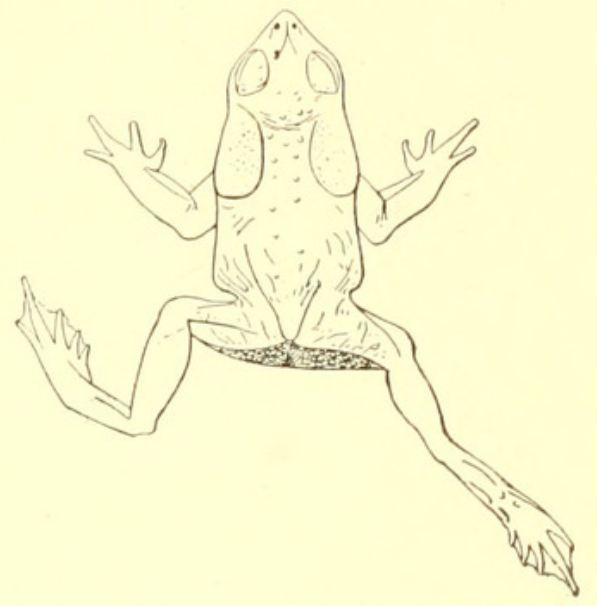

Fig. 1.-BUFo I.ONGINASUS, NATURAL SIZE.

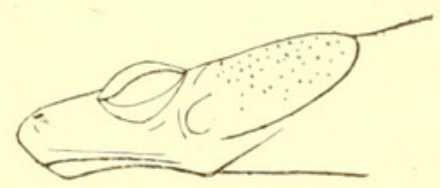

Fig. 4.-BUFo J.onginasus, HEAD FROM SIDE. $2 \times$ NATURAL SIZE.

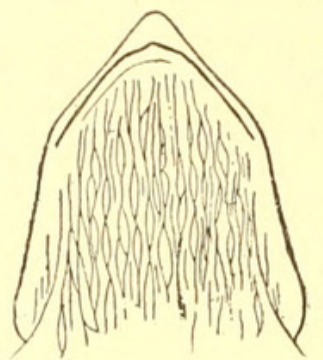

Fig. 2.-BUFO LONGINASUS, THROAT AND CHIN. $2 \times$ NATURAL SIZE.

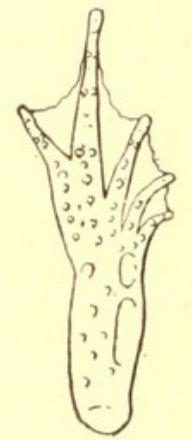

FIG.5.-BUFO LONGINASUS, RIGHT FOOT, UNDER BIDE. $2 \times$ NATURAL SIZE,

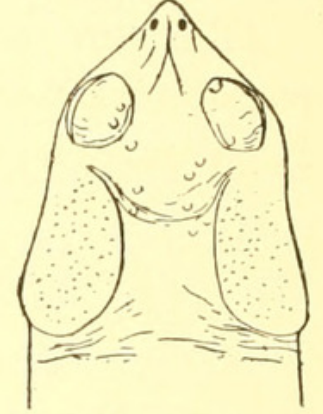

Fig. 3.-BUFO LONGINASUS, TOP OF HEAD AND PARATOIDS. $2 \times$ NATURAL SIZE.

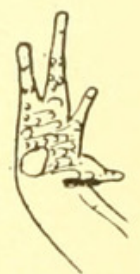

Fig. 6.-BUFO LONGINASUS, RIGHT HAND, UNDER SIDE. $2 \times$ NATURAL SIZE.

their distance from the groin, flat, descending on sides below the level of the tympanum, deeply pitted; throat longitudinally wrinkled on breast and belly, and underside of femurs coarsely granulated. Color (in alcohol) above, dark purplish maroon; underneath, including the upper lip, a narrow space above the insertion of the arm, and the internal half of the upper side of hands and feet white; a few dark purplish brown specks on lips, chest, and tibia and a longitudinal mark of the same color in front of insertion of fore legs. 


\section{Dimensions.}

$\mathrm{mm}$.

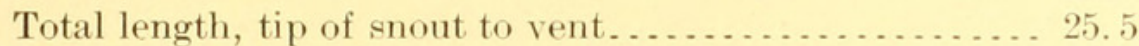

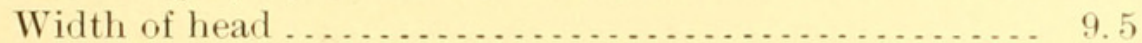

From eye to posterior end of parotoid ........... 7.5

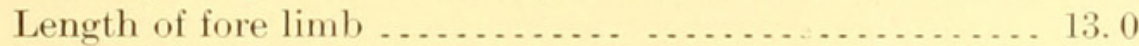

Length of hind limb from vent to tip of longest toe.... . 32.0

Remarks.-The type of this species is the only specimen brought home by the expedition, and as it has thus far escaped all earlier collectors in Cuba, it is apparently quite rare or very local in its distribution. The label indicates that it was captured in a mountain stream.

This new toad is so distinct in every way that it requires no comparison with any of the numerous species composing the genus Bufo. It has no relatives in the other Antilles or in North America. 


\section{$2 \mathrm{BHL}$ Biodiversity Heritage Library}

Stejneger, Leonhard. 1905. "Description of a new toad from Cuba." Proceedings of the United States National Museum 28(1406), 765-767. https://doi.org/10.5479/si.00963801.28-1406.765.

View This Item Online: https://www.biodiversitylibrary.org/item/52788

DOI: https://doi.org/10.5479/si.00963801.28-1406.765

Permalink: https://www.biodiversitylibrary.org/partpdf/51078

\section{Holding Institution}

Smithsonian Libraries

\section{Sponsored by}

Smithsonian

\section{Copyright \& Reuse}

Copyright Status: Public domain. The BHL considers that this work is no longer under copyright protection.

This document was created from content at the Biodiversity Heritage Library, the world's largest open access digital library for biodiversity literature and archives. Visit BHL at https://www.biodiversitylibrary.org. 